\title{
On the Distant and Second Imperfect in Lorrain
}

This study investigates the distribution of the distant imperfect and the second imperfect, an unusual occurrence unknown to other French and Romance dialects, which appears in Lorrain. Although Adam's (1881) descriptive analysis of the distant and second imperfect has been followed by occasional studies, the distributional patterns of the two forms remain overall an unexplored phenomenon and no attempts have been made to examine them from a rigorous, theoretical linguistic perspective.

\section{The Second Imperfect: A brief introduction}

Adam (1881) proposes that the distribution differs in terms of temporal reference: the distant imperfect (i.e., the 'regular imperfect' coming from the Latin imperfect indicative) (1a) refers to a past action that is anchored to a time prior to the speech act whereas the second imperfect (1b) denotes a past action occurring on the same day as the speech act.

1. a, té chantéie distant imperfect

b, té chantézor second imperfect

'you were singing'

Thus, DI denotes an event that occurs in the remote past whereas SI indicates an action occurring in the immediate past, establishing a deictic relationship between the two forms, which is represented in Figure 1:

\begin{tabular}{|c|c|}
\hline \multicolumn{2}{|c|}{ Imperfect } \\
\hline Distant past & Immediate past \\
\hline
\end{tabular}

Figure 1: Bipartite system of Imperfect in Lorrain

\section{Grammaticalization of SI}

Lazarque (1883) attributes the emergence of the second imperfect to a grammaticalization in Old French involving the imperfect and the adverb ores 'maintenant', but he does not provide an account of the different uses of the two forms.

\section{Puisque sus l'amour etions ores \\ because devoted to love were \\ "Because we were devoted to love"}

The data in (2) shows how the contiguity of the demonstrative adverb and the verb may have led to reanalysis, resulting in the formation of SI. A second hypothesis, set forth by Haillant (1883), also merits investigation and proposes that SI grammaticalized in Latin from the affixation of the demonstrative adverb hora 'now'. 


\section{Grammaticalization of Imperfect Construction}

Grammatical remoteness distinctions exist in many of the world's languages today, evidenced by Sanuma ${ }^{1}$ in (3a-b) (de Haan, 2005), and further support the theory that the DI/SI opposition may be a result of grammaticalization in Lorrain.

3. a. ipa sai ha hama töpö hasu-ki ke. my house by visitor 3PL pass.by IMM PAST2

'The visitors passed by my house.'

b. I naha Ĩ a ku-la-so kupili.

like $\quad$ 3SG say DIST PAST ${ }^{3}$

'Like that that one finally said.'

If grammaticalization is responsible for the remoteness distinction in Lorrain, then one expects that grammaticalization is responsible for continued semantic expansion of the entire imperfect construction (e.g. imperfect in Spanish extends to evidential; Haßler, 2002). It is then also possible for evidential categories to semantically extend to other grammatical categories (e.g. modals).

\section{Textual Analysis}

The paper examines the distribution of the DI/SI opposition in texts (two narratives and one play) from three different regions of Lorrain (Vosges, Meurthe-et-Moselle, and Meuse).

\begin{tabular}{|c|c|c|c|c|c|}
\hline Text & Region & Date & DI Tokens & SI Tokens & Total Tokens \\
\hline La jeune fille & Vosges & - & $3(75 \%)$ & $1(25 \%)$ & 4 \\
\hline $\begin{array}{c}\text { Le médecin } \\
\text { malgré lui }\end{array}$ & Meuse & 1778 & $2(25 \%)$ & $6(75 \%)$ & 8 \\
\hline $\begin{array}{c}\text { La femme qui } \\
\text { se noie }\end{array}$ & $\begin{array}{c}\text { Meurthe-et- } \\
\text { Moselle) }\end{array}$ & - & $5(17 \%)$ & $24(83 \%)$ & 29 \\
\hline \begin{tabular}{l} 
Overall Total \\
\hline
\end{tabular}
\end{tabular}

Figure 2: Overview of Lorrain data

My findings suggest that distributional patterns differ with respect to three distinctions (temporal, evidential, and realis) and that perspective (conceptual distance of an event with respect to the speaker) plays an important role in the DI/SI distinction.

First, the results support three distinctions that underlie the distribution of these forms: remoteness (Vosges), evidentiality (Meurthe-et-Moselle), and realis (Meuse).

${ }^{1}$ Amazonian language spoken in Brazil and Venezuela

2 IMM PAST- Immediate past

${ }^{3}$ DIST PAST- Distant past 
Adam's (1881) analysis is consonant with the results found in Vosges (La jeune fille): the distant imperfect corresponds to remote events (larger conceptual distance) and the second imperfect corresponds to immediate events (smaller conceptual distance).

4. a. Dèsque lè jone- lè qu' atot ${ }^{4}$ bougrement As soon as the young girl there who was-IMP-DIST PAST hardly belle $\quad m^{\prime}$ ai $v u$, elle $s^{\prime} \quad$ ai sauvé tot d'in côp. beautiful me had seen she herself had saved all of a sudden

"As soon as the young there who was hardly beautiful had seen me, she fled all of a sudden."

b. Et me val core aiprès le baicelatte. Que se savor And me there running after the young who herself saved-IMP-IMM PAST si vivement.

so quickly

"And there I was running after the small girl. Who escaped so swiftly."

The distributional patterns in the other two regions diverge, losing the temporal aspect. In Meurthe-et-Moselle (Le médecin malgré lui), the distant imperfect is used to express indirect perception of an event (larger conceptual distance) while the second imperfect is used to express direct perception (smaller conceptual distance).

5. L'Arestotte [i] disố $q u$ ' ine foume l'atô-to pû pis que Aristotle he said-IMP-IND that a woman it was-IMP-DIR more worse than l' diâle: l'avô-to maw râjeun'h.

the devil he had-IMP-DIR much raison

"Aristotle, he used to say that a woman was worse than the devil: he was absolutely right."

In Meuse ( $L$ a femme qui se noie), the distant imperfect indicates a non-factive event (larger conceptual distance) whereas the second imperfect reflects a factive one (smaller conceptual distance).

\section{I li é repondu qu' $i$ branciennor béhe-lè}

He them had answered that they tottered-IMP-REALIS over there avo sè fomme, qu' elle èvor cheu è l' eaufe, et qu' with his wife that she had-PLUP-REALIS fallen in the water and that

\footnotetext{
${ }^{4}$ An indirective value may also be contributed to the remoteness distinction based on the slipperiness between direct/indirect evidentials and immediate/remote past.

5 There is ambiguity as to whether this is in fact an indirect evidential or a reportitive evidential, further research is required to make a conclusive judgment.
} 
il lè quoirée.

he her looked for-IMP-IRR

"He answered them that they were tottering over there with his wife, that she had fallen in the water and that he was looking for her."

\section{Summary}

First, grammaticalization might be a motivating factor in the rise of three semantic distinctions (temporal, evidential, and realis) in the imperfect construction in Lorrain.

Second, my analysis attributed the distribution of DI and SI to these three underlying distinctions, which were then related to the construal of the event with respect to the conceptualizer's point of view.

\section{References:}

Adam, Lucien. 1881. Les Patois Lorrains. Paris: Maisonneuve.

de Haan, Ferdinand. 2005. Encoding Speaker Perspective: Evidentials. In Linguistic Diversity and Language Theories. Frajzyngier, Zygmunt, Hodges, Adam, and Rood, David S. (eds.), 379-397. Amsterdam/Philadelphia: John Benjamins.

Haßler, Gerda. 2002. Epistemic Modality and Evidentiality and their determination on a deictic basis: the case of Romance Languages. In Linguistic Realization of Evidentiality in European Languages by Diewald, Gabriele; Smirnova, Elena. 223248. De Gruyter Mouton.

Lazarque Du Montaut, Ernest Auricoste. 1886. "Note sur la formation probable du second imparfait usité dans quelques patois lorrains." Memoire de L'Academie de Metz third ser: 221-230. 